\title{
THE IMPACT OF SMALL GAMES AND FLASHCARDS ON LEARNING THE SKILL OF PASSING FROM THE TOP VOLLEYBALL FOR THE PRIMARY STAGE AT THE AGE OF (11) YEARS
}

\author{
Adi Jamil Shehab \\ Prof.Dr. khalud Layth Abdul Karim \\ University of Baghdad / College of Physical Education and Sports Sciences
}

DOI: $10.37648 / \mathrm{ijrssh.v10i01.017}$

Received:04 ${ }^{\text {th }}$ October 2019; Accepted:23 ${ }^{\text {rd }}$ November, 2019; Published: $03^{\text {rd }}$ December, 2019

\section{ABSTRACT:}

The small games and flashcards (top sport) of educational methods that may be appropriate in the primary stages to ensure the correct construction of the pupil for the next stages, which all teachers must know and find ways to interact with the teacher and his students, so the researcher considered the use of small games and flashcards (top sport) In learning the skill of passing from the top of volleyball that may contribute to finding foundations and facts related to the real contribution to learning this skill, the researchers have assumed there is a positive impact of small games and flashcards on learning skill From the top in volleyball, there is a discrepancy between the three groups (experimental and control) in the level of learning the skill of passing from the top of volleyball, and the researchers identified the research community, which is the fifth primary pupils of the school (trench primary boys) and the Directorate of Education (second Karkh) and the number (102) pupil, the researcher used the experimental method by designing three equal groups equal number two experimental groups and one control so as to suit the nature of the problem, the researcher selected the research sample randomly and lottery method, where the choice was on (36) pupils The first experimental group consisted of (12) pupils (small games) represented by Division (C), the second experimental group (12) pupils flashcards (top sport) represented by the division (A). The control group (12) practice the method followed by the Directorate General of Curriculum / Physical Education and is represented by Division (B). The researcher excluded the students who missed the lessons, repeaters and practitioners of the game, and after collecting data and statistically processing, a number of conclusions were reached.

Keywords: Small games / flashcards. 


\section{INTRODUCTION}

The world community is experiencing an era of human progress and development which has positively reflected on all life facilities, and the educational aspect has had a large share of the advanced peoples, which realized that the learner is the center of the educational process and all the innovations in the curricula and programs in this area but harnessed for its development and in line with progress Accelerated pace in this century.

The small games in the lesson of physical education is of great importance to form a solid structure to develop pupils and provide the necessary supplies in order to progress for the better to ensure the growth of their various aspects, also help the student to be productive and effective for the benefit of the group, and is characterized by the spirit of competition, which is an element of mastery The skill side and upgrade it, to be properly planned during the educational units of the lesson in order to ensure its success in achieving the goals planned for it.

The top sport flashcards are flashcards used in a number of developed countries, whose programs are designed to suit children in the basic stages to come up with a set of interrelated activities.

Therefore, the researchers considered the use of small games and flashcards (top sport) in the development of motor skills and basic skills of volleyball, which may contribute to the foundations and facts related to the real contribution to the development of the abilities and potential of students.

The aim of this research is to prepare small games and flashcards to learn the skills of passing from the top of volleyball to the primary stage at the age of (11) years, to identify the impact of small games and flashcards on learning the skill of passing from the top of volleyball, to identify the preference of the three groups (experimental and control) Learn to scroll from the top of volleyball.

\section{MATERIALS AND METHODS:}

\section{Place of study: Al-Khandaq Elementary School for Boys}

Design Experience:

The researcher used the experimental method to design the three equal groups equal number two experimental groups and one control to suit the nature of the problem. The researcher conducted his first exploratory experiment on Monday (18/2/2019) on a sample of (4) pupils from (A) Change the main sample to avoid difficulties in performing the skill test. Then the pre-test of the research sample was conducted on (Wednesday and Thursday) on (20-21 / 2/2019) after giving a module on skills for each group time (40) $d$ to take an idea of the skill

After the preparation of educational units for small games and flashcards began work on educational units on Tuesday, 26/2/2019, note that the number of educational units was (16) units by two educational units per week and the researcher needed two additional units to learn the skill under research and the result was added two units Without the lessons of physical education to become the number of units (18) units, and the time of each unit (40) d, and the researcher worked within the applied side of the main section, and each educational unit included the main parts of the normal educational unit with the time allocated to it and will join as follows:

:Preparatory section and duration of $10 \mathrm{~d}$, and is in this part the following

) 2 (d Create the requirements of the lesson and perform sports greeting -

) 4 (d Perform general warm-up exercises -

)4 (d Perform effective physical exercises -

:The main section and its duration (25) $\mathrm{d}$ is done in this part

The educational aspect and its duration (5) d: The teacher will explain and clarify the skill to be taught to pupils with their performance in an optimal manner and clarify the most important aspects and common mistakes.

Applied side and duration (20) d: It is the application of games prepared and that serve the development of motor skills and basic skills volleyball. As the teacher divides the pupils into groups according to the games prepared with cards and then illustrates the first game planned in the lesson, which serves the development of research variables In this part, the teacher and student uses the front part of flashcards top sport to explain the games and this part (1-1.5) 
$d$ Then, the pupils apply the game for (3-3.5) d, and after the completion of the performance of any particular game, the teacher releases a whistle with the use of a hand signal to stop playing and this part (30) seconds. And move to the second game totals and so on.

Skill test:

Wall Repeat Test (Hassanein and Abdel Moneim, 1997, pp. 226-230)

Purpose of the test:

Measuring the ability of the laboratory to pass speed and the amount of skill to pass from the top with fingers, and this test is one of the most appropriate tests for the beginners and beginners.

:Tools

A volleyball, a stopwatch, a smooth wall with a parallel line to the ground and a height of $3 \mathrm{~m}$ from the ground, draws a line parallel to the wall on the ground and is $180 \mathrm{~cm}$ away.

:Performance Specifications

The laboratory stands behind the line that is $180 \mathrm{~cm}$ away from the wall (the scroll line), holding the ball with the hands in front of the face and then scrolling towards the wall and the top of the line drawn on it to bounce the ball to reach it again behind the scroll line to continue scrolling from the top with fingers This work for half a minute (30 w)

:the conditions

.Scrolling at all times of performance from behind the line scroll -

.The scroll must be above the line on the wall -

.The calculation of time starts from the first pass for a period of 30 seconds-

.- at the beginning of the test must hold the ball with the hands in front of the face and then perform the scrolling with fingers.

- If the ball out of the wall, or touched the wall below the line drawn on the wall, and bounced in a way that made the laboratory continue to pass in front of the scroll line in all these cases on the laboratory hold the ball and re-start the same way the beginning of the test.

- must use the skill of passing from the top with fingers and other types of other passes.

- The laboratory shall discontinue performance as soon as the judgment expires the prescribed 30-second period.

Registration: The number of times the ball is touched to the wall within (30) seconds of the test, and no attempt to violate the conditions mentioned above is counted. The final score is the number of valid attempts in the (30) seconds multiplied by 3 . The next pass for each stop is the result of a laboratory error.

Research sample: To carry out the research, the researchers determined the research community deliberately, which is the fifth grade pupils of primary school (trench elementary boys) and the Directorate of Education (second Karkh) and the number (102) students. The researcher selected the research sample by random method and the lottery method, where (36) pupils (A, B, and C) were selected to be the sample of the total of (102) pupils by 35.29.

Tools used: Arabic and foreign sources and references, Internet, personal interviews with experts and specialists, data recording and unloading form, performance evaluation form, legal volleyball court, Canon video camera type (1) Tripod for cameras (1), laptop (DELL) (1), volleyball balls (14), stopwatch for measuring time, Fox whistle (2), rubber balls (12), plastic collars Circular number (12), pencils and ink, balls collecting nets (2), shaving basket number (2).

:Statistical means

SPSS statistical package was used to process the research data.

\section{RESULT AND DISCUSSION:}

Display the results of the pre- and post-test tests of the three search groups in the top-pass pass volleyball test Table (1) 
Shows arithmetic media, standard deviations and torsion coefficient for tests of some basic pre- and post-skills skills of the experimental and control groups

\begin{tabular}{|c|c|c|c|c|c|c|}
\hline skewness & $\begin{array}{l}\text { standard } \\
\text { deviation }\end{array}$ & $\begin{array}{l}\text { Arithmetic } \\
\text { mean }\end{array}$ & $\begin{array}{l}\text { The first } \\
\text { pilot }\end{array}$ & $\begin{array}{l}\text { measruing } \\
\text { unit }\end{array}$ & the exams & sequence \\
\hline 0.451- & 0.79781 & 3.6383 & Tribal & Degree & \multirow{2}{*}{$\begin{array}{l}\text { Repeat scrolling } \\
\text { on the wall }\end{array}$} & \multirow[t]{2}{*}{1} \\
\hline 0.806- & 0.89355 & 5.8067 & after me & Degree & & \\
\hline skewness & $\begin{array}{l}\text { standard } \\
\text { deviation }\end{array}$ & $\begin{array}{l}\text { Arithmetic } \\
\text { mean }\end{array}$ & $\begin{array}{l}\text { The first } \\
\text { pilot }\end{array}$ & $\begin{array}{l}\text { measruing } \\
\text { unit }\end{array}$ & the exams & sequence \\
\hline 0.537- & .89289 & 3.4725 & Tribal & Degree & \multirow{2}{*}{$\begin{array}{l}\text { Repeat scrolling } \\
\text { on the wall }\end{array}$} & \multirow[t]{2}{*}{1} \\
\hline 0.869- & .50044 & 6.4442 & after me & Degree & & \\
\hline skewness & $\begin{array}{l}\text { standard } \\
\text { deviation }\end{array}$ & $\begin{array}{l}\text { Arithmetic } \\
\text { mean }\end{array}$ & $\begin{array}{l}\text { The first } \\
\text { pilot }\end{array}$ & $\begin{array}{l}\text { measruing } \\
\text { unit }\end{array}$ & the exams & sequence \\
\hline $0.237-$ & .77736 & 3.2117 & Tribal & Degree & \multirow{2}{*}{$\begin{array}{l}\text { Repeat scrolling } \\
\text { on the wall }\end{array}$} & \multirow[t]{2}{*}{1} \\
\hline 0.769- & .77773 & 5.3325 & after me & Degree & & \\
\hline
\end{tabular}

\section{Table (2)}

Shows the calculated value of $(\mathrm{T})$ and the significance value of the pretest and post test to pass from the top of the volleyball

\begin{tabular}{|c|c|c|c|c|c|c|c|}
\hline $\begin{array}{l}\text { Significance } \\
\text { value }\end{array}$ & $\begin{array}{l}\text { The value } \\
\text { of } \mathrm{T}\end{array}$ & $\mathrm{Kh}-\mathrm{f}$ & $e-f$ & $s-f$ & the group & the exams & sequence \\
\hline 0.000 & 6.899 & .31431 & 1.08879 & $-2.16833-$ & First & \multirow{3}{*}{$\begin{array}{l}\text { Repeat } \\
\text { scrolling on } \\
\text { the wall }\end{array}$} & \multirow{3}{*}{1} \\
\hline .000 & 9.905- & .30002 & 1.03930 & $-2.97167-$ & the second & & \\
\hline 0.005 & 3.489- & .18082 & .62640 & $-.63083-$ & Control & & \\
\hline
\end{tabular}

*Significantly below the significance level $<(0.05)$

Table (3)

Shows the value of the least significant difference (LSD) between the variables in the post test to pass the test from the top and for the experimental and control groups

\begin{tabular}{|l|l|l|l|l|}
\hline $\begin{array}{l}\text { Statistical } \\
\text { significance }\end{array}$ & Error proportions & Circles teams & Aggregates & Variables \\
\hline moral & $\mathbf{0 . 0 1 9}$ & $\mathbf{0 . 6 3 7 5 0} *$ & Experimental 1 & Experimental 1 \\
\hline moral & $\mathbf{0 . 0 0 0}$ & $\mathbf{2 . 1 1 1 6 7} *$ & Officer & \\
\hline
\end{tabular}

Table 15 shows the following:

The existence of significant differences between the first and second experimental group and in favor of the second experimental in the handling of the test from the top, but between the first experimental group and control there are significant differences in favor of the first experimental.

The presence of significant differences between the second experimental group and the control group and in favor of the second experimental in the handling test from the top.

Table (3) shows the following:

The existence of significant differences between the first and second experimental group and in favor of the second experimental in the handling of the test from the top, but between the first experimental group and control there are significant differences in favor of the first experimental. 
The presence of significant differences between the second experimental group and the control group and in favor of the second experimental in the test of higher aphids.

The researcher finds that there are statistically significant differences between the pre and post tests and in favor of the dimension in the pass test from the top. The researcher attributes this to the fact that the educational program with small games and flashcards used has affected them, as the basic skills of volleyball are absolutely necessary in the case of other sports. If we take into consideration that these volleyball skills have the specificity of being recoil and multi-species skills and need high technique so you need to visualize the movement with its various parts in order to reach optimal learning, so the use of Small games and flashcards shares effectively in learning the skill in question, "The use of the best techniques and methods necessary to reach the desired goal will be more speed and proficiency with creativity and renewal" (Abdul Razzaq, 1996, page 4)

The researchers attribute this to the moral differences that occurred in the first and second experimental groups did not come as a result of chance, but following proper planning based on a correct methodology based on scientific basis to identify the strengths and strengthening and weaknesses and try and avoid them, as well as to find appropriate solutions that are compatible with the student's capabilities and potentials And attitudes towards learning the skill involved.

The researchers attribute the differences in favor of the second experimental group (flashcards) to the effectiveness of the teaching method, which was designed to help the process of learning properly, as it focuses on the perception of skill in its partial form, and therefore must pay attention to the sequence of skill and then the full performance, and the performance in this method was developed in accordance with the possibility The learner on the implementation and the type of skill implemented, and thus the researchers believe that the method of the flash card worked to perfect the performance of the skill of passing from the top on the basis of information learner, which generates the necessary expertise and necessary to recognize the sense of movement "The methods and Methods of education play an effective and influential role in the educational process of the curricula to be applied, and these methods and methods vary according to their specificity, as "methods affect the speed of learning and the degree of satisfaction in learning, and that the correct and appropriate adaptation of the method or method depends on a sound understanding of the factors and principles that are relevant to the subject. To prove its impact and value in certain educational situations "(Allawi, 1987, p. 40)

The researcher also attributes the moral differences in favor of the second experimental to the understanding and desire of pupils of the educational cards better than others because these cards are based on the explanation and clarification of the performance and in a variety of games in each educational unit accompanied with information that reaches the pupil from the teacher as well as basic principles underpinning motor learning This has influenced the acquisition of selected skills and points out that "the stages of learning to absorb the duty to be learned by the learner and thus linked to the initial understanding of the movements to be learned and if you want to get effective learning stages, the learner should expect This is important for motivation "(Harah, 1990, p. 36). If we know that there are motives due to the needs of the students led them to easily learn the skill of passing from above.

The method of flashcard is one of the modern means of learning and has won the approval of specialists on the learning process, where the learning process is conducted in an atmosphere predominantly fun and exciting and exciting and cooperation and competition between individuals and positive understanding of the house of students and the teacher and the exchange of knowledge between them and not make the student indoctrination but the truth The learning process down to optimal performance is the desired end.

The method of distributing the exercises used for the second experimental group according to the flashcards, which added the excitement and fun when learning, as well as the various exercises that change from easy to difficult was a factor in achieving a good level of learning. Different and different times as to give continuous information about the cards also has a role in distinguishing them from their peers. 


\section{CONCLUSIONS:}

In light of the results, the researchers concluded the following:

- The results in the post-tests showed a clear development of the three research groups (experimental and control) in learning the skill of passing from the top compared with the tribal tests.

- The methods of small games and flashcards have an effective effect in learning the skill of passing from the top if compared to the method used in the lesson and this is evident in the arithmetic circles that appeared in the post-tests for each group.

- the second experimental group (flashcards) to the first experimental group (small games) in learning the skill of passing from the top in volleyball.

\section{REFERENCES:}

- eabd aljabbar eabd alruzaq. (1996). mqarnt bayn alaslubayn almutadarij waleaksii fi taelam qafzat alyudin ealaa jihaz hisan alqufzati. kuliyat altarbiat alriyadiat - jamieat almawsil.

- muhamad hasan elawy . (1987). sayakliwjiat altadrib walmunafasa . alqahrt: dar almuearif.

- Mohamed Sobhy Hassanein, and Hamdi Abdel Moneim. (1997). Scientific bases of volleyball. Cairo: Book Center for Publishing

Hara (1990). Fundamentals of training. Mosul: Higher Education Press. -

\section{$\operatorname{ANNEX}(1)$}

Shows models with small toys

Toy (22)

Name of the game: Ttbba ball with one hand and return the other

Objective of the game: Learn to scroll from the top

Tools used: volleyball court, volleyball, whistle, signs.

Way of play: Divide the pupils into two groups, each group 6 pupils, Tbtba ball with one hand running down to the middle of the stadium and turn around the person and back to the other hand to the colleague.

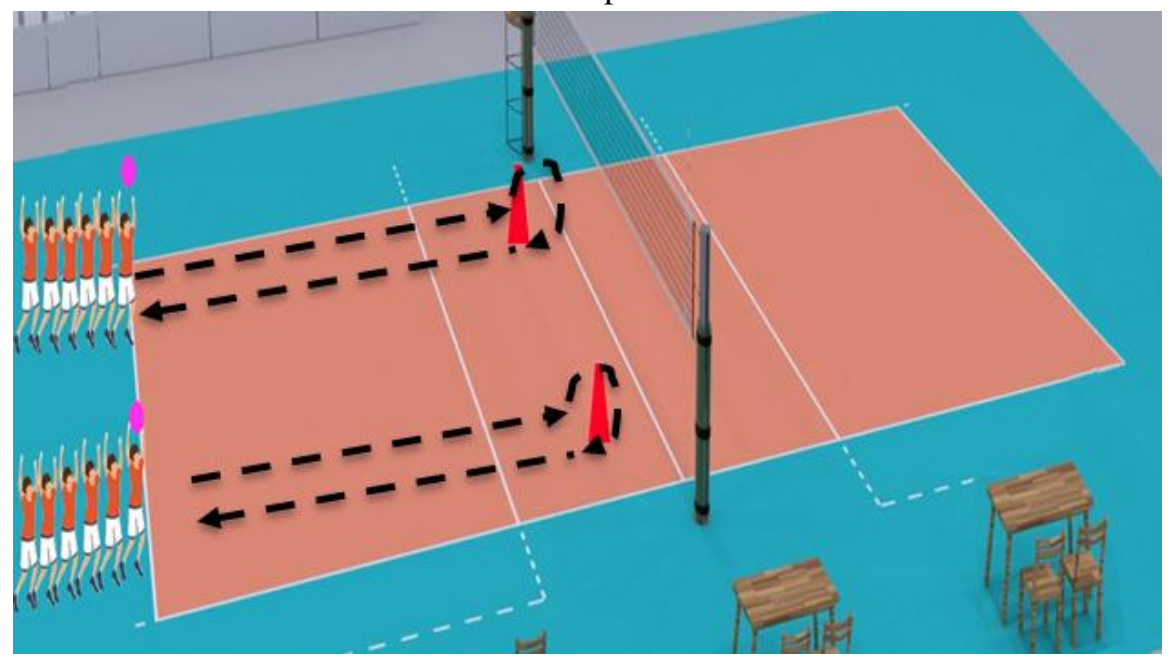

Toy (22)

Name of the game: Scrolling from the top inside the basket shaved 
Objective of the game: Learn to scroll from the top

Tools used: volleyball court, volleyball balls, whistle, shaving basket.

Playing the game: Divide the row in two groups standing on the final line of the stadium, the game begins to set up and then scroll from the top up to the goal of the throat and after $3 \mathrm{~m}$ is passed, the winning group of intervention the largest number of balls during $3 \mathrm{~d}$.

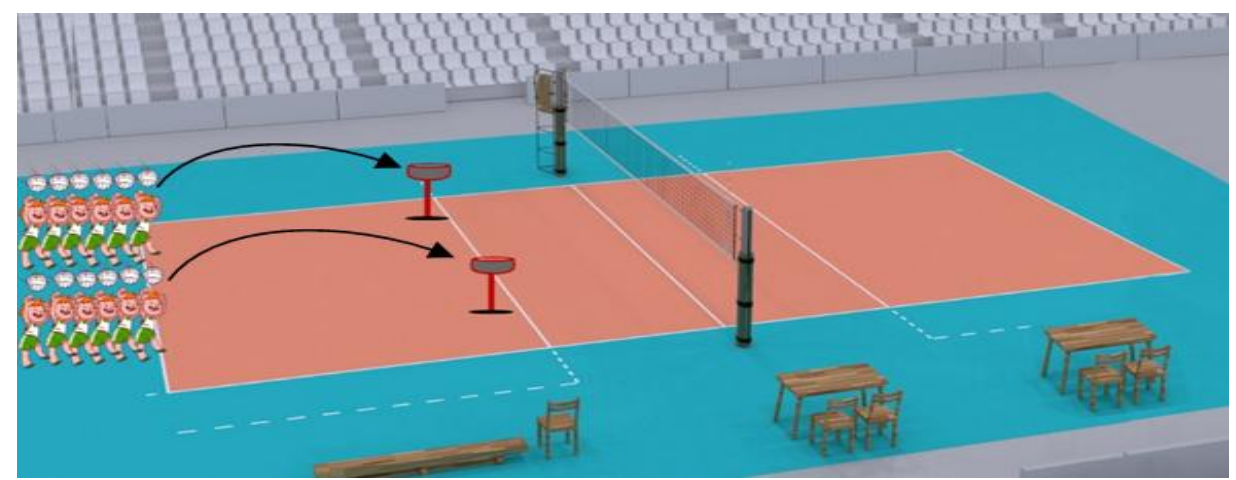

Unit 6 (Experimental Group II)

Grade and Division: Fifth Time Unit: $40 \mathrm{~d}$

Number of pupils: 12 Week: Third

Educational Objectives: Teaching the skill of passing from the top Educational objectives: playing the role, sparking the spirit of competition and cooperation time

the week

Educational Goals

\begin{tabular}{|c|c|c|c|c|}
\hline Notes & Organization & Activities and skills & Time & $\begin{array}{l}\text { Educational } \\
\text { Unit } \\
\text { Departments }\end{array}$ \\
\hline & & & $10 \mathrm{~m}$ & $\begin{array}{l}\text { Preparatory } \\
\text { Section }\end{array}$ \\
\hline $\begin{array}{l}\text { Emphasize order } \\
\text { and calm. }\end{array}$ & $\begin{array}{l}x \times \times \times \times \times \times \times x \times \\
x\end{array}$ & $\begin{array}{l}\text { Preparing the requirements of the } \\
\text { lesson and taking absences and } \\
\text { performing sports greeting }\end{array}$ & $2 \mathrm{~m}$ & \\
\hline $\begin{array}{l}\text { Emphasize the } \\
\text { warming of all } \\
\text { body parts. }\end{array}$ & $\begin{array}{l}\times \times \times \times \times \times \times \times \\
\times\end{array}$ & $\begin{array}{l}\text { Perform jogging exercises with the } \\
\text { arms rotated in front of behind and } \\
\text { perform front and side wheels of the } \\
\text { feet. }\end{array}$ & $4 \mathrm{~m}$ & $\begin{array}{l}\text { - General } \\
\text { warm-up }\end{array}$ \\
\hline \multirow[t]{2}{*}{$\begin{array}{l}\text { Emphasize the } \\
\text { performance of the } \\
\text { exercise properly }\end{array}$} & $\begin{array}{l}\times \times \times \times \times \times \times \times \times \times \times \\
\times\end{array}$ & Performing special exercises. & $4 \mathrm{~m}$ & $\begin{array}{l}\text { - Warm up } \\
\text { your }\end{array}$ \\
\hline & & & $25 \mathrm{~m}$ & $\begin{array}{l}\text { Main section } \\
\text { Bawshar }\end{array}$ \\
\hline $\begin{array}{lr}\text { Emphasize correct } \\
\text { performance } \\
\text { correct and }\end{array}$ & & $\begin{array}{l}\text { Explain and teach pupils how to } \\
\text { scroll skill from the top }\end{array}$ & $5 \mathrm{~m}$ & $\begin{array}{l}\text { - The } \\
\text { educational } \\
\text { aspect }\end{array}$ \\
\hline
\end{tabular}




\begin{tabular}{l|l|l|l|l|}
\hline $\begin{array}{l}\text { constantly. } \\
\text { Perform the games } \\
\text { properly }\end{array}$ & Model (6) & $20 \mathrm{~m}$ & - Applied side \\
$\begin{array}{l}\text { Perform the sports } \\
\text { greeting with } \\
\text { enthusiasm, } \\
\text { emphasize re-tools } \\
\text { and leave quietly. }\end{array}$ & $\begin{array}{l}\text { Perform relaxation exercises and } \\
\text { inform students of the next lesson } \\
\text { material and then perform the sports } \\
\text { greeting and leave. }\end{array}$ & $5 \mathrm{~m}$ & Final Section \\
\hline
\end{tabular}

Acquire and develop skills

To encourage children to:

Maintain body balance -

- Take the correct situation when performing

- Return to standby mode after playing ball

- Focus on the ball that the player passes

\begin{tabular}{l} 
Adaptation and diversification \\
\begin{tabular}{|l|l|}
\hline Level harder & Level easier \\
Zoom distances & Reduce distances \\
You can add people & Leave the task without signs \\
Minimize goals & Zoom goals \\
Use of legal volleyball & Ball lighter \\
& \\
\hline
\end{tabular} \\
\hline
\end{tabular}

\begin{tabular}{|l|l|}
\hline $\begin{array}{l}\text { Performance evaluation and development } \\
\begin{array}{l}\text { Explanation of the reason for ease of scrolling on a larger } \\
\text { target }\end{array}\end{array}$ & $\begin{array}{l}\text { This step aims to encourage children to: } \\
\text { Note the performance of the colleague and try to perform } \\
\text { optimally } \\
\begin{array}{l}\text { Dialogue to learn errors } \\
\text { Direct the ball to the selected area } \\
\text { Clarify the difference between different } \\
\text { areas of the place }\end{array}\end{array}$ \\
& $\begin{array}{l} \\
\end{array}$
\end{tabular}




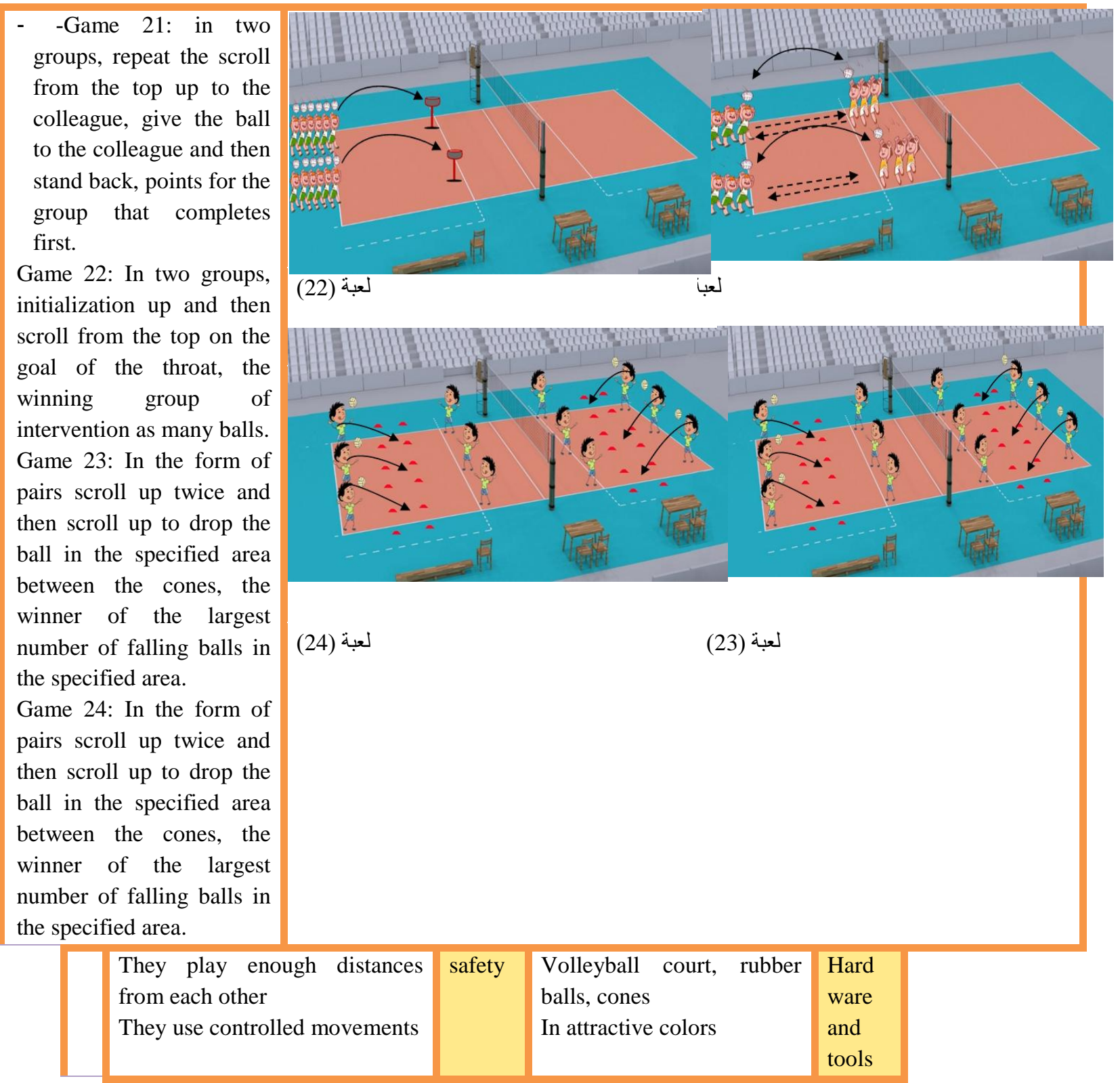

